\title{
PENGARUH APLIKASI dSRNA VP-15 IN VITRO DAN IN VIVO TERHADAP SINTASAN DAN RESPONS IMUN UDANG WINDU Penaeus monodon
}

\author{
Andi Parenrengi ${ }^{*}$ Andi Tenriulo, Sri Redjeki Hesti Mulyaningrum, Samuel Lante, \\ dan Agus Nawang
}

Balai Riset Perikanan Budidaya Air Payau dan Penyuluhan Perikanan

Jl. Makmur Dg. Sitakka No. 129, Maros 90511, Sulawesi Selatan

(Naskah diterima: 16 September 2019; Revisi final: 11 Oktober 2019; Disetujui publikasi: 14 Oktober 2019)

\begin{abstract}
ABSTRAK
Teknologi RNA interference (RNAi) merupakan salah satu pendekatan yang digunakan untuk meningkatkan resistensi udang windu terhadap infeksi patogen termasuk WSSV. Pengembangan teknologi RNAi melalui aplikasi untai ganda RNA (dsRNA) yang berasal dari gen pengkode viral protein (VP) dari WSSV telah mulai dikembangkan pada udang. Penelitian ini bertujuan untuk mengkaji sintasan dan respons imun udang windu yang diberi VP-15 pasca uji tantang dengan WSSV. Udang windu (panjang 15,21 $\pm 1,19 \mathrm{~cm}$ dan bobot 32,5 $\pm 1,83 \mathrm{~g}$ ) diinjeksi dengan $0,2 \mu \mathrm{g}$ /ekor dsRNA in vitro (A), dsRNA in vivo (B), dan larutan garam/ kontrol (C). Setelah tiga hari vaksinasi, udang windu ditantang dengan WSSV dengan dosis $50 \mu \mathrm{L} / \mathrm{ekor}$. Pengamatan sintasan dilakukan setiap hari, sedangkan respons imun (THC dan aktivitas proPO) dilakukan pada awal dan hari ke-1, ke-3, dan ke-5 pasca uji tantang, serta analisis ekspresi gen antivirus dan histopatologi hepatopankreas dilakukan pada akhir penelitian. Hasil penelitian menunjukkan bahwa aplikasi dsRNA berpengaruh nyata $(\mathrm{P}<0,05)$ terhadap sintasan, THC, dan proPO. Sintasan udang windu yang diberi dsRNA VP-15 in vitro dan in vivo memberikan sintasan yang lebih tinggi 75\%dibandingkan dengan kontrol. Nilai proPO tertinggi didapatkan pada dsRNA in vivo $(0,138)$; kemudian dsRNA in vitro $(0,093)$; dan terendah kontrol $(0,061)$; sedangkan THC tertinggi $\left(5.704 \times 10^{4} \mathrm{sel} / \mathrm{mL}\right)$ pada dsRNA in vivo, kemudian dsRNA in vitro $\left(3.516 \times 10^{4} \mathrm{sel} / \mathrm{mL}\right)$ dan terendah pada perlakuan kontrol $\left(3.322 \times 10^{4} \mathrm{sel} / \mathrm{mL}\right)$. Ekspresi gen antivirus semakin meningkat dengan semakin lamanya udang windu terpapar dengan WSSV. Jaringan hepatopankreas udang windu pada perlakuan kontrol (tanpa dsRNA) menunjukkan adanya kerusakan sel akibat infeksi virus.
\end{abstract}

\section{KATA KUNCl: $\quad$ dsRNA VP-15; in vitro; in vivo; udang windu; uji tantang}

ABSTRACT: The effects of in-vitro and in-vivo dsRNA application to survival rate and immune response of tiger shrimp, Penaeus monodon. By: Andi Parenrengi, Andi Tenriulo, Sri Redjeki Hesti Mulyaningrum, Samuel Lante, and Agus Nawang

RNA interference (RNAi) technology is one of the approaches used to improve tiger shrimp Penaeus monodon resistance against WSSV infection. The development of RNAi technology through double-stranded RNA (dsRNA) isolated from gene encoding viral protein (VP) of WSSV has been applied to shrimp. This study was aimed to assess the survival rate and immune response of injected-VP-15 WSSV tiger shrimp after a challenge with WSSV. The tiger shrimp (15.21 \pm $1.19 \mathrm{~cm}$ in length and $32.5 \pm 1.83 \mathrm{~g}$ in weight) were injected with $0.02 \mu \mathrm{g} / \mathrm{shrimp}$ of in vitro dsRNA (A), in vivo dsRNA (b) and saline solution $(C)$. After three days of vaccination, the tiger shrimp were challenged with W SSV using a dosage of $50 \mu \mathrm{L} /$ shrimp. The survival rate was observed daily. Analyses of immune responses (hemocyte total and PO activity) were performed in several stages: before the challenge test and day-1, day-3, and day- 5 post-challenge test. The expression of the antivirus gene and hepatopancreas histophatology were was observed at the end of the experiment. The results showed that the application of dsRNA significantly influenced the shrimp survival rate, THC, and proPO. Tiger shrimp injected with dsRNA VP-15 of in vitro and in vivo exhibited a higher $75 \%$ survival rate than the control $(\mathrm{P}<0.05)$. The highest proPO activity $(0.138)$ was obtained at dsRNA in vivo, followed by dsRNA in vitro $(0.093)$ and

\footnotetext{
\# Korespondensi: Balai Riset Perikanan Budidaya Air Payau dan

Penyuluhan Perikanan. Jl. Makmur Dg. Sitakka No. 129,

Maros 90511, Sulawesi Selatan, Indonesia.

Tel. + 62411371544

E-mail: andi_parenrengi@ hotmail.com
} 
the lowest $(0.061)$ in the control. The highest THC $\left(5,704 \times 10^{4} \mathrm{cell} / \mathrm{mL}\right)$ was in vivo dsRNA, then in vitro dsRNA $\left(3,516 \times 10^{4} \mathrm{cell} / \mathrm{mL}\right)$, and the lowest in the control $\left(3,322 \times 10^{4} \mathrm{cell} / \mathrm{mL}\right)$. The longer the exposure with WSSV, the higher the antivirus geneexpression. Histopathology analysis showed some damages to thehepatopancreas cells in the control shrimp (without dsRNA) caused by the virus infection.

\section{KEYWORDS: dsRNA VP-15; in vitro; in vivo; tiger shrimp; challenged test}

\section{PENDAHULUAN}

Pendekatan rekombinan DNA khususnya vaksin DNA telah mulai diaplikasikan pada akuakultur. Penerapan bioteknologi pada akuakultur dalam peningkatan resistensi ikan atau udang melawan serangan penyakit atau patogen merupakan salah satu alternatif pemecahan masalah penyakit. Selain itu, mekanisme yang potensial dalam peningkatan resistensi penyakit adalah produksi hewan akuatik melalui penerapan interferensi RNA (RNA interferenceRNAi) atau juga dikenal sebagai teknologi untai ganda RNA (double-stranded RNA-dsRNA). RNAi merupakan suatu teknologi yang dapat menghambat ekspresi gen virulensi dari virus.

Aplikasi bioteknologi dalam upaya pemecahan masalah penyakit khususnya pada krustase dilakukan dengan pendekatan yang berbeda. Penemuan gen pengkode antimikroba penaeidin membuka peluang dalam peningkatan immunitas udang melawan serangan patogen pada udang Litopenaeus vannamei (Destoumieux et al., 1997). Induksi imun pada udang melalui vaksinasi telah dilaporkan dengan penggunaan rekombinan protein WSSV pada udang Penaeus chinensis (Kim et al., 2004) dan antivirus menggunakan dsRNA pada udang L. vannamei (Robalino et al., 2004). Penerapan RNAi telah menghasilkan suatu terobosan dalam produksi ternak khususnya pada ayam (CSIRO, 2014). Wulandari (2010) melaporkan bahwa aplikasi dsRNA Gonadal Inhibiting Hormone $(\mathrm{GIH})$ secara in vitro dan in vivo dapat menstimulasi pematangan gonad pada udang windu.

Mekanisme RNAi pada hewan akuatik khususnya krustase terjadi pada beberapa tahap, di mana pada saat dsRNA diinduksi ke dalam sel target terlebih dahulu terjadi pembentukan siRNA yang kemudian mendegradasi mRNA sehingga ekspresi gen secara spesifik menjadi inaktif pada tahap post-transkripsi (Reshi et al., 2014; He et al., 2015). Aplikasi vaksin dsRNA khususnya gen virulensi penkode viral protein (VP) dari WSSV pada udang windu masih sangat terbatas. Sebagai langkah awal, telah dilakukan karakterisasi gen penyandi VP-15 dan VP-24 dari WSSV dan aplikasi dsRNA yang diproduksi secara in vitro (Tenriulo et al., 2016; Parenrengi et al., 2017; Parenrengi et al., 2018; Mulyaningrum et al., 2018). Produksi dsRNA secara in vitro menggunakan kit masih terkendala dalam hal biaya produksi yang tinggi dan hasil produksi relatif sedikit. Oleh karena itu, perlu dilakukan upaya produksi secara in vivo agar dapat dilakukan dengan mudah dalam jumlah yang relatif besar karena dapat diproduksi melalui bakteri. Penelitian ini dilakukan dengan tujuan untuk mengkaji pengaruh aplikasi dsRNA VP-15 yang diproduksi secara in vitro dan in vivo terhadap sintasan dan respons imun udang windu pasca uji tantang dengan WSSV.

\section{BAHAN DAN METODE}

\section{Hewan Uji}

Hewan uji yang digunakan adalah udang windu P. monodon dengan ukuran bobot dan panjang masingmasing adalah $32,5 \pm 1,83 \mathrm{~g}$ dan 15,21 $\pm 0,19 \mathrm{~cm}$. Hewan uji yang berasal dari tambak pembesaran, Instalasi Pembenihan Udang Windu (IPUW) Barru, diaklimatisasi di bak Gedung Karantina, IPUW Barru, BRPBAP3 dan selanjutnya dilakukan pengecekan kesehatan udang khususnya infeksi WSSV dengan menggunakan teknik PCR. Hewan uji yang digunakan pada penelitian ini adalah udang windu yang dinyatakan negatif atau bebas infeksi WSSV.

\section{Produksi Vaksin dsRNA Secara In Vitro}

Isolasi gen target VP-15 dilakukan dari genom DNA udang windu positif terinfeksi penyakit WSSV. Setelah itu, dilakukan konstruksi gen VP-WSSV dengan promoter T7 dengan cara menambahkan sekuens promoter pada setiap primer. Amplifikasi DNA dilakukan pada mesin PCR, dengan menggunakan kit sebagai reaksi PCR dan $1 \mu \mathrm{L}(50 \mathrm{\rho mol} / \mathrm{mL})$ masing-masing primer dan $\mathrm{dH}_{2} \mathrm{O}$ untuk mencapai volume akhir $25 \mu \mathrm{L}$. Proses PCR dilakukan dengan program pre-denaturasi pada $94^{\circ} \mathrm{C}$ selama tiga menit; 35 siklus (denaturasi pada $94^{\circ} \mathrm{C}$ selama satu menit, annealing pada $57^{\circ} \mathrm{C}$ selama 45 detik, dan ekstensi pada $72^{\circ} \mathrm{C}$ selama satu menit); dan ekstensi akhir pada $72^{\circ} \mathrm{C}$ selama lima menit. Hasil PCR selanjutnya diel ektroforesis pada gel agarosa 2\%untuk keperluan dokumentasi. Amplikon PCR dielekroforesis pada gel agarosa untuk mengetahui keberhasilan pembentukan konstruksi gen.

Produksi vaksin dsRNA VP-15 secara in vitro, dilakukan menggunakan kit MEGAscript RNAi (Loy et al., 2012). Konstruksi gen VP-15 dengan promoter T7 dari plasmid bakteri rekombinan dijadikan sebagai bahan dasar (template DNA) untuk perbanyakan vaksin 
rekombinan dsRNA. Proses produksi dsRNA melalui tahapan: (a) perbanyakan dsRNA; (b) digesti dsRNA; dan (c) pemurnian dsRNA. Verifikasi produksi dsRNA dilakukan dengan metode elektroforesis. Untuk menentukan konsentrasi vaksin dsRNA, hasil produksi diukur dengan menggunakan GeneQuan pada panjang gelombang $260 \mathrm{~nm}$ dan $280 \mathrm{~nm}$ (Linacero et al., 1998).

\section{Produksi Vaksin dsRNA Secara In Vivo}

Produksi vaksin dsRNA VP-WSSV dilakukan melalui kloning gen target ke dalam vektor RNAi dan selanjutnya ditransformasikan ke bakteri kompeten sel sehingga konstruksi gen dapat dilakukan pada bakteri rekombinan (Parenrengi et al., 2018). Pengklonan gene penyandi VP-WSSV dilakukan dengan cara fragmen DNA dari amplikon PCR yang telah dielektroforesis dalam agarosa gel dipotong, kemudian DNA diisolasi dan dimurnikan dengan kit GF-1 Gel Recovery. Selanjutnya fragmen DNA direstriksi berdasarkan enzim restriksi yang sesuai, kemudian diligasikan ke vektor L4440 yang mengandung promoter T7 dan selanjutnya ditranformasi ke bakteri kompeten Escheria coli DH5 $\alpha$. Transformasi bakteri dilakukan melalui teknik kejut panas (heat shock) dengan mencampurkan $5 \mu \mathrm{L}$ hasil ligasi dengan 100 $\mu \mathrm{L}$ sel kompeten bakteri dalam tabung mikro pada kondisi dingin. Hasil pencampuran tersebut diinkubasi pada suhu $42^{\circ} \mathrm{C}$ selama 30 detik sebagai perlakuan kejut panas dan dipindahkan ke dalam es selama 10 menit. Campuran gen VP yang sudah ditransformasi ke dalam sel kompeten dipindahkan ke tabung polipropilena volume $15 \mathrm{~mL}$ dan ditambahkan media LB $1 \mathrm{~mL}$. Kemudian diinkubasi pada suhu $37^{\circ} \mathrm{C}$ dengan rotaryshaker $120 \mathrm{rpm}$ (satu jam) dan disentrifugasi dengan kecepatan $6.000 \mathrm{rpm}$ selama lima menit. Skrining koloni E. coli DH5 $\alpha$ yang mengandung plasmid rekombinan (T7-VP) dilakukan dengan metode seleksi koloni berwarna putih dan biru. Koloni putih yang diduga mengandung insert gen VP-15 digunakan sebagai template. Koloni putih ditumbuhkan pada media LB cair dalam test tube $15 \mathrm{~mL}$, kemudian diinkubasi selama satu malam menggunakan shaker suhu $37^{\circ} \mathrm{C}$ dengan kecepatan $120 \mathrm{rpm}$. Panen bakteri dilakukan dengan cara disentrifugasi dengan kecepatan 5.000 rpm selama lima menit dan pelet yang terbentuk digunakan sebagai template untuk PCR. Isolasi plasmid dari bakteri rekombinan dilakukan dengan menggunakan kit isolasi plasmid dengan mengikuti metode yang disarankan oleh vendor (GENEAID). Konsentrasi plasmid DNA konstruksi gen VP-15 vaksin dsRNA dihitung dengan menggunakan GeneQuan pada panjang gelombang $260 \mathrm{~nm}$ dan $280 \mathrm{~nm}$ (Linacero et al., 1998).

\section{Aplikasi Vaksin dsRNA VP-15 WSSV}

Aplikasi dsRNA pada penelitian ini difokuskan pada validasi metode produksi dsRNA pada udang windu, yang terdiri dari tiga perlakuan, yakni: (A) perlakuan injeksi vaksin dsRNA dosis $0,2 \mu \mathrm{g}$ yang diproduksi secara in vivo; (B) perlakuan injeksi vaksin dsRNA dosis $0,2 \mu \mathrm{g}$ yang diproduksi secara in vitro; dan (C) perlakuan injeksi larutan fisiologis (kontrol). Setiap perlakuan masing-masing memiliki tiga ulangan.

Aplikasi vaksin dsRNA dilakukan melalui injeksi inter-muscular ke udang windu. Hewan uji yang telah divaksin dipelihara pada bak fiber $250 \mathrm{~L}$ dengan kepadatan 10 ekor/bak menggunakan media air laut 32 ppt yang dilengkapi dengan aerasi dan pemberian pakan pelet $4 \%$ per bobot tubuh sebanyak tiga kali sehari. Setelah tiga hari vaksinasi, udang diuji tantang dengan WSSV dengan volume $50 \mu \mathrm{L} / \mathrm{ekor}$ (konsentrasi berdasarkan data LC-50 pada penelitian sebelumnya) melalui injeksi, dan selanjutnya dipelihara dengan kepadatan dan wadah yang sama dengan saat vaksinasi. Sintasan udang windu pasca uji tantang diamati setiap hari selama 12 hari. Untuk mengetahui pengaruh dsRNA terhadap respons imun udang uji, maka dilakukan pengambilan hemolim sebelum uji tantang, kemudian hari ke-1, 3, dan 5 setelah uji tantang pada tiga ekor udang windu. Pada akhir penelitian dilakukan analisis ekspresi gen antivirus dan histopatologi pada organ hepato pankreas. Parameter respons imun yang diamati adalah:

\section{Total Hemocyte Count (THC)}

Pengamatan THC dilakukan dengan mengambil hemolim 0,1 $\mathrm{mL}$ pada abdomen segmen kedua dengan menggunakan syringe $1 \mathrm{~mL}$ dan jarum berukuran 26 gauge yang sudah berisi $0,3 \mathrm{~mL}$ antikoagulan $\mathrm{Na}$-sitrat $3,8 \%$ Jumlah sel hemosit dihitung dengan menggunakan haemositometer di bawah mikroskop pembesaran 100 kali dengan rumus yang dikembangkan oleh Blakxhall \& Daishley (1973).

\section{Aktivitas Prophenoloxydase (proPO)}

Aktivitas proPo diukur berdasarkan formasi dopachrome yang dihasilkan oleh L-dihydroxyphenil alanine (L-Dopa) dengan menggunakan spektrofotometer. Pengukuran aktivitas PO mengacu pada prosedur Liu $\&$ Chen (2004). Sebanyak 0,1 $\mathrm{mL}$ hemolim ditambah dengan $0,9 \mathrm{~mL}$ antikoagulan lalu dihomogenkan dalam Effendorf. Campuran ini kemudian disentrifuge dengan kecepatan $700 \times$ g pada $4^{\circ} \mathrm{C}$ selama 20 menit. Cairan supernatan dibuang dan pelet dibilas dengan $1 \mathrm{~mL}$ cocodilate-citrate buffer ( $0,01 \mathrm{M}$ sodium cacodylate; 0,45 $\mathrm{M}$ sodium chloride; $0,10 \mathrm{M}$ trisodium citrate; $\mathrm{pH}$ 7) dan 
disentrifuge kembali dengan kecepatan dan kondisi yang sama. Supernatan dibuang dan pelet dilarutkan dangan cacodylatebuffer $(0,01 \mathrm{M}$ sodium cacodylate; 0,45 M sodium klorida; 0,01 M kalsium klorida; 0,26 M magnesium klorida; pH 7). Larutan kemudian dibagi dua masing-masing sebanyak $100 \mu \mathrm{L}$. Larutan pertama diinkubasi dengan $50 \mu \mathrm{L}$ trypsin $(1 \mathrm{mg} / \mathrm{mL}$ cacodylate buffer) sebagai aktivator sedangkan larutan kedua ditambahkan $50 \mu \mathrm{L}$ cacodylate buffer (pengganti tripsin). Kedua-duanya diinkubasi selama 10 menit pada suhu $25^{\circ} \mathrm{C}-26^{\circ} \mathrm{C}$. Selanjutnya masing-masing ditambah $50 \mu \mathrm{L}$ L-DOPA ( $3 \mathrm{mg} / \mathrm{mL}$ cacodylate buffer) dan lima menit kemudian ditambahkan $800 \mu \mathrm{L}$ cacodilate buffer. Aktivitas PO diukur menggunakan spektrofotometer dengan panjang gelombang absorban $490 \mathrm{~nm}$. Densitas optikal (OD) dari aktivitas PO pada semua kondisi uji dinyatakan sebagai formasi dopachrome dalam $50 \mu \mathrm{L}$ hemolim.

\section{Ekspresi Gen dan Histopatologi}

Ekspresi gen pada udang windu dilakukan dengan isolasi RNA dengan menggunakan kit isolasi RNA dan selanjutnya dilakukan sintesis cDNA untuk dijadikan sebagai template DNA untuk proses. Amplifikasi DNA dilakukan melalui teknik PCR dengan dengan mengacu pada metode yang telah dikembangkan oleh Parenrengi et al. (2009a; 2009b). Keberadaan fragmen DNA pada posisi sekitar 520 bp pada genom DNA dan pada cDNA merupakan indikator keberadaan dan terekspresinya gen antivirus tersebut. Ekspresi gen â-aktin udang windu digunakan sebagai kontrol ekspresi gen.

Untuk mengetahui pengaruh vaksin dsRNA terhadap infeksi WSSV maka dilakukan analisis histopatologi organ hepatopankreas. Hepatopangreas diawetkan dengan etanol $100 \%$ sebelum dilakukan analisis histologi di Balai Besar Penelitian Veteriner, Kementerian Pertanian di Maros.

\section{Analisis Data}

Untuk mengetahui pengaruh perlakuan terhadap sintasan dan respons imun udang (THC dan aktivitas proPO) udang windu pasca uji tantang, maka data dianalis menggunakan analisis ragam (ANOVA), dan uji lanjut menggunakan LSD pada taraf kepercayaan 0,05 . Hasil pengamatan produksi dsRNA, ekspresi gen, serta histopatologi dianalisis secara deskriptif.

\section{HASIL DAN BAHASAN}

\section{Produksi dsRNA VP-15 WSSV}

Produksi vaksin dsRNA VP-15 secara in vitro dan konstruksi gen PT7-VP15 yang dijadikan sebagai bahan dasar pembentukan vaksin dsRNA telah berhasil dilakukan padan udang windu. Sedangkan dsRNA secara in vivo juga telah berhasil diproduksi melalui bakteri rekombinan. Verifikasi keberhasilan produksi dsRNA secara in vivo dan in vitro dilakukan dengan metode elektroforesis (Gambar 1).

Keberadaaan fragmen DNA pada posisi sekitar 253 bp, merupakan indikator keberhasilan dalam mengisolasi dan memproduksi vaksin dsRNA VP-15 (Parenrengi et al., 2018). Gambar 1 menunjukkan bahwa produksi dsRNA berhasil dilakukan dengan tingkat kemurniaan yang sangat tinggi yakni 1,8-1,9; serta ditandai dengan pita DNA tunggal yang bersih. Linacero et al. (1998) telah merekomendasikan bahwa kemurnian DNA untuk kegiatan molekuler sebaiknya berada pada kisaran 1,8-2,0. Kuantitas produksi dsRNA secara in vitro sangat tergantung dari kit yang digunakan. Penggunaan kit MEGAScript RNAi menghasilkan volume produksi sebanyak $400 \mu \mathrm{L}$, sedangkan produksi dsRNA secara in vivo dapat dilakukan dengan volume yang lebih besar sepanjang produksi bakteri rekombinan dapat dilakukan dengan massal.

\section{Sintasan}

Udang windu sampai dengan hari ke-4 pasca uji tantang memperlihatkan sintasan yang masih cukup tinggi dan belum memperlihatkan perbedaan antara perlakuan yang dicobakan (Gambar 2). Perlakuan kontrol mempelihatkan penurunan sintasan sampai dengan 20\% pada hari ke-3 pasca uji tantang, dan selanjutnya kematian yang relatif besar pada hari ke-5 (kumulatif sintasan $55 \%$ dan berlangung terus sampai mencapai kematian total pada hari ke-12. Sedangkan perlakuan dsRNA VP-15 baik in vitro maupun in vivo pada hari ke-5 sampai dengan hari ke-10 memperlihatkan kematian yang relatif sedikit dan setelah hari ke-10 memperlihatkan sintasan yang stabil sampai dengan penelitian berakhir. Sintasan udang windu yang divaksin dengan dsRNA in vitro dan in vivo memperlihatkan sintasan yang lebih tinggi $(75 \%)$ dibandingkan dengan kontrol $(P<0,05)$.

Gambar 2 menunjukkan bahwa pola kematian udang windu yang diberi dsRNA VP-15 yang diproduksi secara in vitro relatif sama dengan perlakuan dsRNA in vivo di mana setelah hari ke-10 tidak lagi mengalami kematian. Hal ini diduga karena udang windu yang diberi dsRNA telah melakukan perlawanan terhadap infeksi dengan sistem peningkatan respons imum dan penghambatan ekspresi gen virulensi WSSV yang menyebabkan tidak patogen. Mekanisme in-aktivasi gen virulensi pada virus telah digambarkan oleh Mocellin \& Provenzano (2004) dan Reshi et al. (2014) melalui beberapa tahap, yakni: (1) untaian panjang dsRNA (long dsRNA) dipotong oleh enzim RNAse-III 

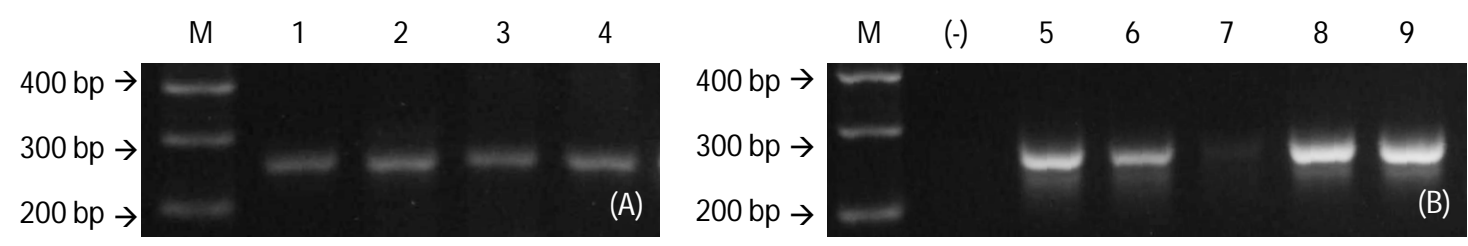

Gambar 1. Elektroforesis dsRNA VP-15 hasil produksi secara in vitro menggunakan kit MEGAscript (A) dan in vivo yang diisolasi dari plasmid rekombinan DNA (B). $M=$ marker DNA; 1-4= dsRNA VP-15 in-vitro; 5-9= dsRNA VP-15 secara in vivo; dan (-)= kontrol negatif.

Figure 1. Electhrophoresis of VP-15 dsRNA produced by in vitro using M EGAscript RNAi Kit (A) and by in vivo isolated from DNA plasmid of bacteria recombinant (B). $M=$ DNA marker; 1-4 = VP. 15 dsRNA in vitro; $5-9=$ VP-15 dsRNA in vivo; and $(-)=$ negative control.

melalui mekanisme dicer menjadi fragmen-fragmen kecil yang panjangnya sekitar 19-23 nukleotida dengan 2-4 nukleotida overhang pada ujung 3'. Hasil potongan ini disebut small interfering RNA (siRNA) yang selanjutnya memicu terjadinya RNAi pada sel target. Proses pemotongan dsRNA oleh RNAse-III tidak memerlukan ATP tetapi oleh aktivitas enzim nuklease; (2) beberapa fragmen siRNA berikatan dengan kompleks protein RISC (RNA-induced silencing complex) yang akan memandu mengenal mRNA yang berisi sekuen homolog, selanjutnya kedua sekuens ini akan berkomplemen, dan setelah berkomplemen maka enzim nuklease yang ada pada kompleks RISC akan mendegradasi mRNA; dan (3) setelah mRNA terdegradasi maka ekspresi gen secara spesifik menjadi inaktif pada tahap post-transkripsi.
Studi pendahuluan yang dilakukan sebelumnya oleh Parenrengi et al. (2018) menunjukkan bahwa dengan aplikasi dsRNA VP-15 dapat meningkatkan sintasan udang windu hingga 36,7\%dibandingkan dengan tanpa penggunaan vaksin atau kontrol $(3,3 \%)$ atau setara dengan nilai RPS (relative percentage survival) sebesar $37,9 \%$ Pengamatan terhadap sintasan udang windu selama uji tantang pemberian vaksin dsRNA VP-24 dengan dosis 0,2 ig memperlihatkan peningkatan sintasan yang signifikan pada udang windu sebesar $65 \%$ dibandingkan kontrol hanya 10\%(Mulyaningrum et al., 2018). Peningkatan sintasan pada udang yang divaksin dengan dsRNA dari serangan WSSV telah dilaporkan sebelumnya oleh Krishnan et al. (2009) sebesar 62\% Sarathi et al. (2010) sebesar 37\% dan Puneeth et al. (2017) sebesar 50\%pada udang windu.

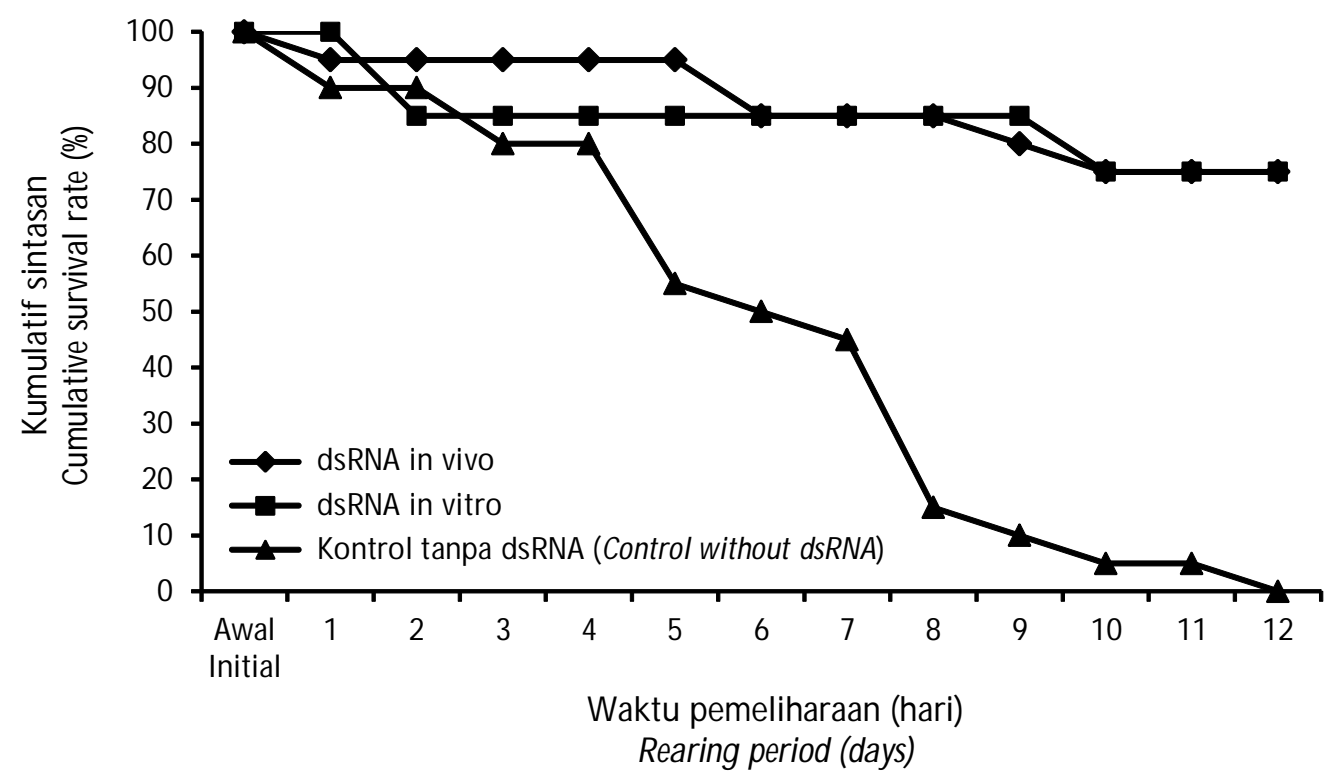

Gambar 2. Kumulatif sintasan udang windu yang diberi dsRNA VP-15 in vitro dan in vivopasca uji tantang dengan WSSV.

Figure 2. Cumulative survival rate of tiger shrimp vaccinated with in vitro and in vivo dsRNA VP-15 after challenged with WSSV. 
Penggunaan vaksin dsRNA dengan dosis $2,0 \mu \mathrm{g}$ pada udang $L$. vannamei dapat meningkatkan sintasan $100 \%$ melawan IHNV (Loy et al., 2012). Aplikasi vaksin VP26 dan VP-28 pada udang P. japonicus dapat meningkatkan resistensinya dengan nilai RPS masingmasing 80\% dan 95\% (Namikoshi et al., 2004), sedangkan aplikasi dsRNA VP-28 pada Macrobrachium rosenbergii menghasilkan RPS sebesar 44,5\%terhadap WSSV (Jariyapong et al., 2015). Vaksinasi udang windu dengan menggunakan VP-19 melalui pakan dapat meningkatkan sintasan dengan nilai RPS sebesar 77\% pada hari ke-7 dan 29\% pada hari ke-21 setelah uji tantang dengan WSSV (Witteveldt et al., 2004). Pada hari ke-9 setelah ditantang dengan WSSV, udang L. vannamei yang diinjeksi dengan plasmid yang mengandung VP-28, VP-39, dan wsV-477 memperlihatkan sintasan masing-masing 50\% 60\% dan $90 \%$ dibandingkan dengan kontrol $10 \%$ (Akhila et al., 2015).

\section{Aktivitas Prophenoloxydase (proPO)}

Nilai proPO untuk semua perlakuan memperlihatkan kecenderungan semakin meningkat dengan semakin lamanya udang windu terpapar dengan WSSV (Gambar 3a). Perlakuan dsRNA in vitro dan in vivo memperlihatkan perlawanan yang relatif lebih kuat dengan terjadinya peningkatan nilai proPO yang lebih tinggi dibandingkan dengan kontrol. Hal ini menununjukkan bahwa aplikasi dsRNA VP-15 dapat memberikan perlawanan melalui peningkatan proPOnya. Pengamatan pada aktivitas proPO sebelum dan sesudah uji tantang dengan WSSV memperlihatkan bahwa ProPO tertinggi diperoleh pada pemberian vaksin dsRNA in vivo $(0,138)$; kemudian diikuti dengan perlakuan dsRNA in vitro yakin 0,093 dan terendah perlakuan kontrol sebesar 0,061 (Gambar 3b).

Hasil analisis ragam (ANOVA) memperlihatkan bahwa perlakuan vaksin dsRNA memberikan pengaruh yang nyata pada aktivitas proPO $(\mathrm{P}<0,05)$; di mana aktivitas proPO tertinggi didapatkan pada perlakuan dsRNA VP-15 in vivo dan selanjutnya in vitro dan kontrol. Hasil penelitian ini juga mengungkapkan bahwa aktivitas proPO semakin meningkat dengan semakin lamanya hewan uji terpapar dengan WSSV. Hal yang sama juga didapatkan pada aplikasi dsRNA VP-24, di mana aktivitas proPO udang windu meningkat pada 24 jam hingga 72 jam setelah ditantang dengan WSSV (Mulyaningrum et al., 2018). Sedangkan Paria et al. (2013) melaporkan bahwa uji tantang WSSV pada pengujian dsRNA VP-28 tidak memberikan perubahan yang signifikan pada ekspresi gen proPO udang windu hingga 24 jam, namun terjadi peningkatan ekspresi hingga tiga kali lipat pada 48 jam setelah injeksi. ProPO merupakan komponen mayor pada sistem imunitas innate pada udang atau yang dikenal dengan istilah sistem kekebalan nonspesifik seluler dan humoral yang keduanya aktif dan bekerja secara bersama-sama saat terjadi tantangan kekebalan. Tassanakajon et al. (2013) menjelaskan bahwa di antara berbagai jenis respons kekebalan humoral, salah satu teknik imun invertebrata yang paling efektif melawan partikel asing adalah enkapsulasi melanotik seluler, atau melanisasi yang merupakan komponen pertahanan imun pada krustasea di mana sintesis melanin dilakukan dengan mengaktivasi sistem proPO yang melibatkan enzim

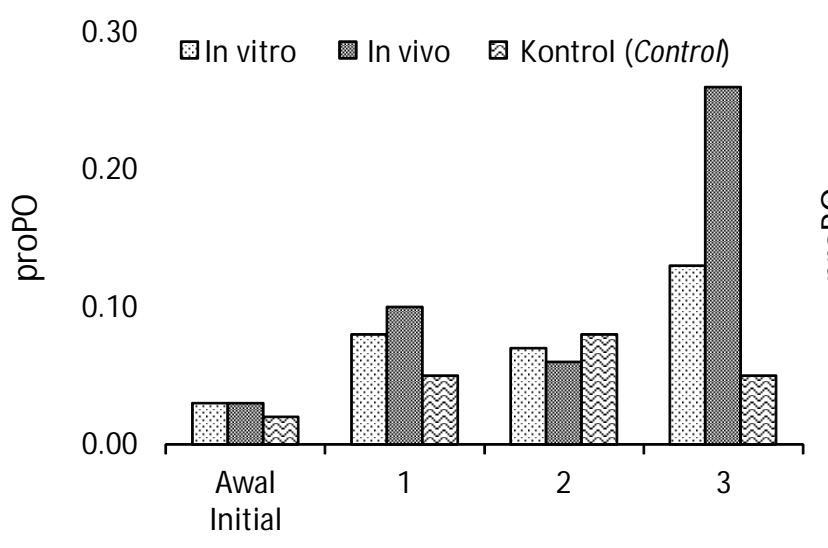

Pengamatan (hari) / Observation (days)

(a)
$0.20 \square$ In vitro $\square$ In vivo $\quad$ Kontrol (Control)

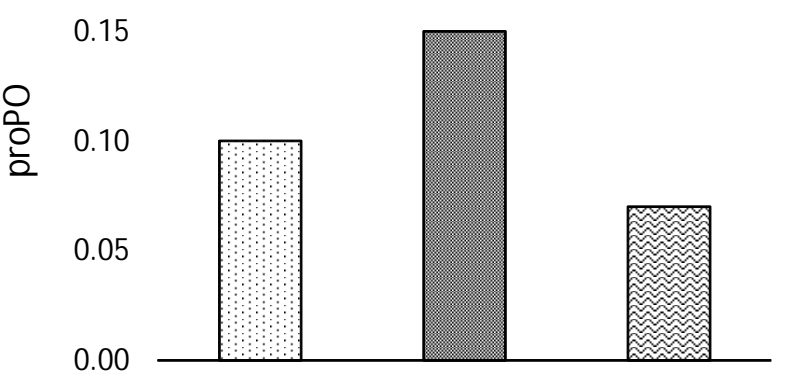

Gambar 3. Nilai proPO udang windu sebelum dan hari ke-1, ke-3, dan ke-5 pasca uji tantang dengan WSSV (a) dan nilai rata-rata proPO udang windu pasca uji tantang (b).

Figure 3. The proPO value of tiger shrimp before and day-1, day-3, and day-5 after challenged with WSSV (a) and average of proPO value of tiger shrimp after challenged with WSSV (b). 
PO sehingga aktivitas proPO meningkat. Sementara penurunan aktivitas sistem proPO dapat menyebabkan kegagalan fagositosis dan menyebabkan kerusakan jaringan (Amparyup et al., 2013).

\section{Total Haemocyte Count (THC)}

THC merupakan salah satu parameter gambaran darah yang dapat digunakan untuk mendeteksi tinggirendahnya resistensi udang windu. Pola perlawanan udang windu melalui pengamatan respons imun THC memperlihatkan kecenderungan semakin meningkat setelah dilakukan uji tantang dengan WSSV (Gambar 4a). Udang windu baik yang diberi vaksin dsRNA maupun kontrol memberikan perlawanan terhadap infeksi patogen dengan indikator meningkatnya jumlah THC, kecuali pada hari ke-3 pasca uji tantang terjadi penurunan yang walaupun relatif kecil. Tren nilai THC tersebut relatif sama dengan respons imun udang windu lainnya seperti nilai proPO yang juga cenderung terjadi penurunan pada hari ke-3. Penurunan THC pasca uji tantang umumnya disebabkan oleh bermigrasinya sel hemosit dari sistem sirkulasi tubuh menuju jaringan akibat banyaknya sel yang terinfeksi (Yeh et al., 2009).

Pengamatan THC udang windu pasca uji tantang menunjukan bahwa perlakuan dsRNA in vivo memperlihatkan rata-rata THC yang lebih tinggi yakni $5.704 \times 10^{4} \mathrm{sel} / \mathrm{mL}$, kemudian aplikasi dsRNA in vitro sebesar $3.516 \times 10^{4} \mathrm{sel} / \mathrm{mL}$ dan terendah pada perlakuan kontrol yakni $3.322 \times 10^{4} \mathrm{sel} / \mathrm{mL}$ (Gambar 4b). Hasil analisis ragam menunjukkan bahwa perlakuan pemberian vaksin dsRNA berpengaruh nyata $(P<0,05)$ terhadap jumlah THC dalam hemolim udang windu. Hasil penelitian Mulyaningum et al. (2018) menunjukkan bahwa aplikasi vaksin dsRNA VP-24 memberikan pengaruh yang nyata terhadap jumlah THC pada hemosit udang windu, di mana dosis yang optimal adalah $0,2 \mu \mathrm{g} /$ ekor dengan jumlah THC sebesar $1.550 \times 10^{4} \mathrm{sel} / \mathrm{mL}$.

Peningkatan jumlah THC merupakan salah satu upaya pertahanan udang dalam meningkatkan resistensinya terhadap infeksi patogen. Hasil penelitian ini menunjukkan bahwa penggunaan dsRNA yang diproduksi secara in vivo memberikan efek peningkatan THC tertinggi dengan semakin lamanya terpapar WSSV. Peningkatan sel-sel hemosit dalam tubuh udang berperan penting dalam menghambat atau menghancurkan patogen yang masuk ke dalam tubuh udang. Pada krustase, termasuk udang windu, terdapat tiga jenis utama sel darah, yakni: sel hialin, sel semigranular, dan sel granular, yang berperan dalam kekebalan tubuh dan pertahanan terhadap infeksi penyakit (Cerenius et al., 2010; Rowley \& Pope, 2012). Seperti halnya dengan vaksin, pemberian imunostimulan pada udang yang dilakukan secara terusmenerus dapat mengatur dan mempertahankan sistem imun pada kondisi optimal sampai dengan pemberian berhenti dilakukan (Jane et al., 2015).

\section{Ekspresi Gen Antivirus dan Histopatologi Hepatopankreas}

Ekspresi gen merupakan salah satu parameter yang dapat digunakan dalam mengetahui pertahanan tubuh atau resistensi udang windu. Gen PmAV merupakan gen antivirus yang umumnya dapat diekspresikan pada udang windu pada beberapa jaringan khususnya di jaringan hepatopankreas dengan menggunakan ekspresi gen $\beta$-aktin sebagai kontrol internal

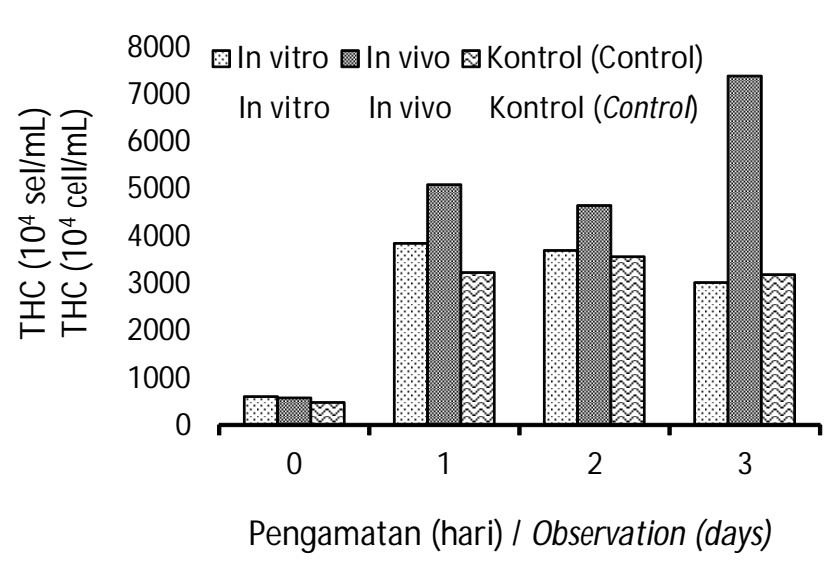

(a)

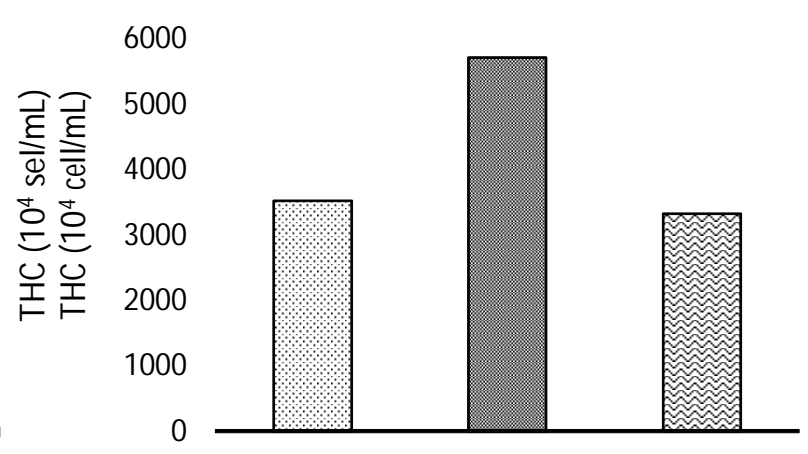

(b)

Gambar 4. THC udang windu sebelum dan hari ke-1, ke-3, dan ke-5 pasca uji tantang dengan WSSV (a) dan nilai rata-rata THC udang windu pasca uji tantang (b).

Figure 4. The THC of tiger shrimp before and day-1, day-3, and day-5 after challenged with WSSV (a) and average of THC value of tiger shrimp after challenged with WSSV (b). 
(Parenrengi, 2010). Keberhasilan analisis ekspresi gen udang windu pada riset ini ditandai dengan tereksresinya gen $\beta$-aktin pada sintesis CDNA yang diisolasi dari udang windu. Fragmen DNA tunggal pada posisi sekitar 400 bp dan kontrol negatif tanpa band pada posisi tersebut (Gambar 5a). Gambar tersebut menunjukkan intensitas ekspresi yang relatif sama sehingga menjadi indikator keberhasilan isolasi cDNA dan proses PCR sudah berlangsung dengan baik.

Analisis ekspresi gen antivirus pada penelitian ini menunjukkan adanya kecenderungan meningkatnya ketebalan pita ekspresi gen antivirus dari awal sampai dengan pengamatan hari ke-5 yang menandakan terjadinya perlawanan infeksi virus yang semakin meningkat. Analisis semi-kuantitaif ini memperlihatkan bahwa pada awal sebelum uji tantang belum terlihat adanya ekspresi gen antivirus tetapi setelah uji tantang ekspresi gen semakin meningkat pada hari ke-1 dan relatif bertahan pada hari ke-3 dan hari ke-5 (Gambar 5b). Ekspresi gen pada aplikasi dsRNA in vivo memperlihatkan ekspresi yang relatif lebih tinggi (ekspresi terlihat jelas pada hari ke-1, ke3, dan ke-5) dibandingkan dengan kontrol. Meskipun demikian aplikasi dsRNA in vitro relatif sama dengan kontrol (tanpa aplikasi dsRNA VP-15). Teknologi RNAi dapat secara langsung merusak WSSV tetapi juga dapat menginduksi gen-gen respons imun (Mocellin \& Provenzano, 2004; Robalino et al., 2004; Reshi et al., 2014); oleh karena itu, ekspresi gen antivirus yang relatif sama antara perlakuan dsRNA in vitro dengam kontrol diduga akibat respons dsRNA yang lebih banyak terjadi pada proses langsung merusak patogen dibandingkan dengan menginduksi gen antivi rus udang windu. Meskipun demikian mekanisme tersebut secara detail masih diperlukan penelitian secara kuantitatif yang lebih mendalam.
Analisis histopatologi juga dapat dijadikan indikator perlawanan organisme terhadap infeksi pada udang windu. Kematian udang windu pasca uji tantang pada penelitian menunjukkan adanya infeksi WSSV yang dibuktikan dengan teknik PCR. Selain analisis tersebut, kematian udang windu atau kerusakan jaringan dapat diketahui dengan analisis histo patologi. Histopatologi dilakukan pada jaringan hepatopankreas udang windu untuk mengetahui hubungan antara kerusakan jaringan akibat infeksi virus dengan sintasan udang windu yang divaksin maupun tidak divaksin. Pengamatan histopatologi udang uji pada aplikasi vaksin VP-15 menunjukkan bahwa jaringan hepatopankreas udang tanpa vaksin mengalami abnormalitas bila dibandingkan dengan udang yang diberi vaksin baik in vitro maupun in vivo (Gambar 6). Setelah adanya uji tantang WSSV, hepatopankreas udang windu tanpa vaksin mengalami tingkat kerusakan inti sel lebih tinggi dibandingkan dengan udang yang divaksin dsRNA, yang ditandai dengan masih banyaknya sel-sel yang masih normal. Kerusakan jaringan hepatopankreas udang windu akibat adanya infeksi WSSV telah dilaporkan oleh Firmansyah (2002) dan Rahmawati (2002) yang ditandai adanya badan inklusi yang sentronuklear, eosinofilik, dan terpisah dari membran sel, dan akhirnya kemudian benangbenang kromatin menepi. Mulyaningrum et al. (2018) memperlihatkan adanya beberapa tingkat kerusakan sel jaringan akibat adanya infeksi WSSV pada udang windu, seperti inklusi badan, nekrotik sel, peningkatan degenerasi lemak, dan lisis sel pada hepatopankreas. Perbandingan antara jaringan hepatopankreas udang windu setelah ditantang dengan WSSV telah dilaporkan sebelumnya oleh Parenrengi et al. (2018) di mana aplikasi vaksin dsRNA memperlihatkan kerusakan yang lebih rendah dibandingkan dengan udang windu kontrol atau tanpa perlakuan penggunakan dsRNA.
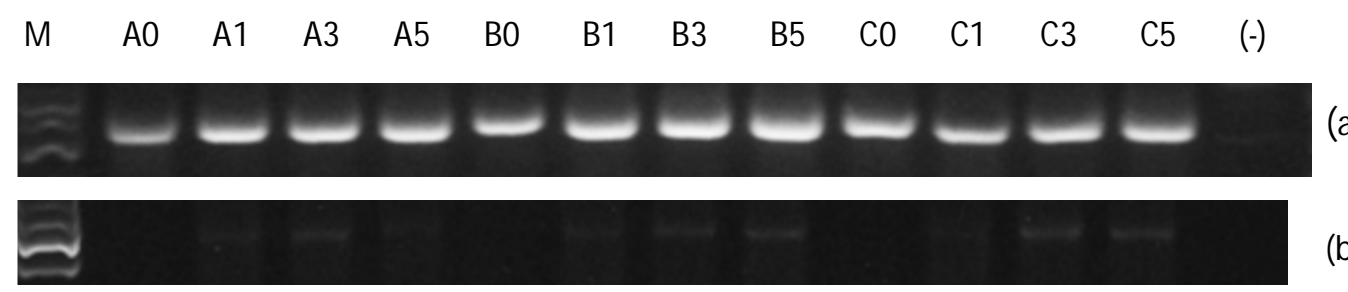

(b)

Gambar 5. Ekspresi gen â-aktin (a) dan antivirus PmAV (b) udang windu pasca uji tantang dengan WSSV. $M=$ marker DNA, $A=$ dsRNA in vitro, $B=$ dsRNA in vivo, $(-)=$ kontrol negatif, $0=$ awal, $1=$ hari ke- $1,3=$ hari ke-3, dan $5=$ hari ke-5.

Figure 5. Expression of â-actin gene (a) and antiviral PmAV gene (b) of tiger shrimp after challenged with WSSV. $M=$ DNA marker, $A=$ in vitro dsRNA, $B=$ in vivo dsRNA, $C=$ control without dsRNA, $(-)=$ negative control, $0=$ initial, $1=$ day- $-1,3=$ day -3 , and $5=$ day -5 . 


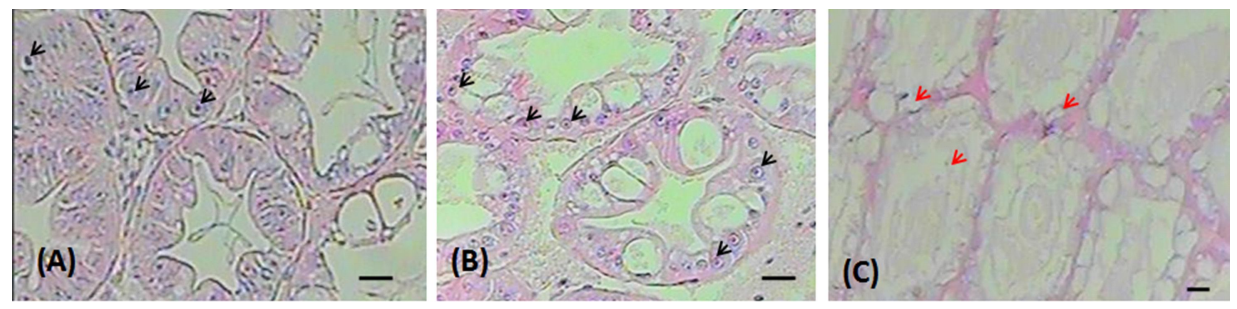

Gambar 6. Gambaran histopatologi hepatopankreas udang windu yang ditantang dengan WSSV (skala bar $=20 \mu \mathrm{m} ; \mathrm{A}=$ vaksin dsRNA in vitro; $\mathrm{B}=$ vaksin dsRNA in vivo; $C=$ kontrol (tanpa dsRNA); dan tanda panah hitam menunjukkan inti sel normal, dan tanda panah merah menunjukkan lisis inti sel).

Figure 6. Histophatolgy profile of tiger shrimp hepatopacreas after challenged with WSSV (bar scale $=20 \mu \mathrm{m} ; A=$ in vitro dsRNA; $B=$ in vivo dsRNA; $C=$ control (without dsRNA); and black arrow = normal nucleus cell; and red arrow $=$ cell lysis).

\section{KESIMPULAN}

Produksi dsRNA VP-15 WSSV baik secara in vitro menggunakan kit MEGAscript RNAi maupun secara in vivo melalui kloning gen telah berhasil dilakukan. Aplikasi vaksin dsRNA VP-15 WSSV menunjukkan bahwa udang windu yang diberi dsRNA VP-15 baik in vivo maupun in vitro memperlihatkan resistensi lebih tinggi terhadap infeksi WSSV, di mana sintasan dan respons imun (proPO dan THC) lebih baik dibandingkan dengan kontrol (tanpa dsRNA). Hasil penelitian ini berimplikasi bahwa aplikasi dsRNA (khususnya yang diproduksi secara in vivo) memiliki prospek yang baik untuk dikembangkan dalam upaya penanggulangan penyakit pada biota akuakultur.

\section{DAFTAR ACUAN}

Akhila, D.S., Mani, M.K., Rai, P., Condon, K., Owens, L., \& Karunasagar, I. (2015). Antisense RNA mediated protection from white spot syndrome virus (WSSV) infection in Pacific white shrimp Litopenaeus vannamei. Aquaculture, 435, 306-309.

Amparyup, P., Charoensapsri, W., \& Tassanakajon, A. (2013). Prophenoloxidase system and its role in shrimp immune responses against major pathogens. Fish \& Shellfish Immunology, 34, 990-1001.

Blakxhall, P. \& Daishley, K. (1973). Some blood parameters of the rainbow trout I. The Kamloops variety. J. Fish. Biol., 5, 1-8.

Cerenius, L., Jiravanichpaisal, P., Liu, H., \& Söderhäll, I. (2010). Crustacean immunity. In Söderhäll, K. (Ed.). Invertebrateimmunity. New York, USA: Landes Bioscience and Springer Science Business Media, wLLC, p. 239-258.
CSIRO (2014). Biosecurity: Protecting Australia, CSIRO Biosecurity Flagship. Paper presented at Workshop CSIRO-BPPT. August $19^{\text {th }} 2014$, in Jakarta.

Destoumieux, D., Bulet, P., Loew, D., Dorsselaer, A.V., Rodriguez, J., \& Bachere, E. (1997). Penaeidins, a new family of antimicrobial peptide isolated from the shrimp Penaeus vannmaei (Decapoda). J. Biol. Chem., 272(45), 28398-28496.

Firmansyah, A. (2002). Uji patogenitas white spot syndrome virus (WSSV) pada udang windu (Penaeus monodon Fabr.). Skripsi. Fakultas Perikanan dan IImu Kelautan, Institut Pertanian Bogor. Bogor, $88 \mathrm{hlm}$.

He, Y., Jua, C., \& Zhanga, X. (2015). Roles of small RNAs in the immune defense mechanisms of crustaceans. Molecular Immunology, 68, 399-403.

Jane, M.S., Amar, A., \& Amar, E.C. (2015). Use of immunostimulans in shrimp culture: An update. Biotechnological advances in shrimp health management in the Philippines. Research Signpost, p. 45-71.

Jariyapong, P., Chotwiwatthanakun, C., Direkbusarakom, S., Hirono, I., Wuthisuthimethavee, S., \& Weerachatyanukul, W. (2015). Delivery of double stranded RNA by Macrobrachium rosenbergii nodavirus-like particles to protect shrimp from white spot syndrome virus. Aquaculture, 435, 86-91.

Kim, D.K., Jang, I.K., Seo, H.C., Shin, S.O., Yang, S.Y., \& Kim, J.W. (2004). Shrimp protected from WSSV disease by treatment with egg yolk antibodies (IgY) against a truncated fusion protein derivated from WSSV. Aquaculture, 237, 21-30. 
Krishnan, P., GireshBabu, P., Saravanan, S., Rajendran, K.V., \& Chaudhari, A. (2009). DNA constructs expresing long-hairpin RNA (IhRNA) protects Penaeus monodon against white spot syndrome virus. Vaccine, 27, 3849-3855.

Linacero, R., Rueda, J., \& Vazquez, A.M. (1998). Quantification of DNA. p. 18-21, In Isaac, G. \& Ingram, D.S. (Ed.). Molecular Tools for Screening Biodiversity: Plants and Animals. London, Weinheim, New York, Tokyo, Melbourne, Madras: Chapman and Hall.

Liu, C.H. \& Chen, J.C. (2004). Effect of ammonia on the immune response of white shrimp Litopenaeus vannamei and its susceptibility to Vibrio alginolyticus. Fish Shellfish Immunol., 16, 321-334.

Loy, J.D., Mogler, M.A., Loy, D.S., Janke, B., Kamrud, K., Scura, E.D., Harris, D.L.H., \& Bartholomay, L.C. (2012). dsRNA provides sequence-dependent protection against infectious myonecrosis virus in Litopenaeus vannamei. Journal of General Virology, 93, 880-888.

Mocellin, S. \& Provenzano, M. (2004). RNA interference: learning gene knock-down from cell physiology. Journal of Translational Medicine, 2(39), 6 pp.

Mulyaningrum, S.R.H., Parenrengi, A., Tampangallo, B.R., \& Trismawanti, I., (2018). Respons imun udang windu Penaeus monodon terhadap vaksin dsRNA VP24 pada dosis berbeda. Jurnal Riset Akuakultur, 13(1), 77-84.

Namikoshi, A., Wu, J.L., Yamashita, T., Nishizawa, T., Nishioka, T., Arimoto, M., \& Muroga, K. (2004). Vaccination trials with Penaeus japonicas to induce resistence to white spot syndrome virus. Aquaculture, 229(1), 25-35.

Parenrengi, A., Alimuddin, Sukenda, Sumantadinata, K., Yamin, M., \& Tenriulo, A. (2009a). Cloning of ProAV promoter isolated from tiger prawn Penaeus monodon. Indonesian Aquaculture Journal, 4(1), 1-7.

Parenrengi, A., Alimuddin, Sukenda, Sumantadinata, K., \& Tenriulo, A. (2009b). Karakteristik sekuens cDNA pengkode gen antivirus dari udang windu, Penaeus monodon. Jurnal Riset Akuakultur, 4(1), 1-13.

Parenrengi, A. (2010). Peningkatan resistensi udang windu Penaeus monodon terhadap penyakit white spot syndrome virus melalui transfer gen Penaeus monodon antiviral. Disertasi. Sekolah Pascasarjana, Institut Pertanian Bogor. Bogor, $108 \mathrm{hlm}$.

Parenrengi, A., Alimuddin, \& Tenriulo, A., (2017). Characteristics of viral protein, VP-15, of whitespot syndrome virus isolated from infected tiger shrimp Penaeus monodon (Fabricius, 1798). Indonesian Aquaculture Journal, 12(2), 67-75.
Parenrengi, A., Mulyaningrum, S.H.R., Tenriulo, A., \& Nawang, A., (2018). Gen penyandi viral protein 15 (VP-15) white spot syndrome virus (WSSV) dan aplikasinya sebagai vaksin rekombinan pada udang windu. Jurnal Riset Akuakultur, 13(1), 57-65.

Paria, A., Greeshma, S.S., Chaudhari, A., Makesh, M., Purushothaman, C.S., \& Rajendran, K.V. (2013). Nonspecific effect of double-stranded (ds) RNA on prophenoloxidase (proPO) expression in Penaeus monodon. Appl. Biochem. Biotechnol., 169, 281-289.

Puneeth, T.G., Akhila, D.S., Dechamma, M.M., Shreeharsha, J.M., Shivakumar, S.K., \& Venugopal, M.N. (2017). Comparative efficacy of dsRNA VP24, VP26, RR1 and WSV477 gene against WSSV infection in Penaeus monodon. Int. J. Curr. Microbiol. App. Sci., 6(2), 665-674.

Rahmawati, R. (2002). Uji patogenitas white spot syndrome virus (WSSV) pada udang windu (Penaeus monodon Fabr.) melalui metode perendaman dengan konsentrasi $200 \mu \mathrm{g} / \mathrm{mL}$ selama 30, 60, dan 90 menit. Skripsi. Fakultas Perikanan dan IImu Kelautan, Institut Pertanian Bogor. Bogor, $80 \mathrm{hlm}$.

Reshi, M.L., Wu, J.L., Wang, H.V., \& Hong, J.R. (2014). RNA interference technology used for the study of aquatic virus infections. Fish \& Shellfish Immunology, 40, 14-23.

Robalino, J., Browdy, C.L., Prior, S., Metz, A., Parnell, P., Gross, P., \& Warr, G. (2004). Induction of antiviral immunity by double-stranded RNA in a marine invertebrata. J. Virol., 78, 10442-10448.

Rowley, A.F. \& Pope, E.C. (2012). Vaccines and crustacean aquaculture: A mechanistic exploration. Aquaculture, 334-337, 1-11.

Sarathi, M., Simon, M.C., Venkatesan, C., Thomas, J., Ravi, M., Madan, N., Thiyagarajan, S., \& Hameed, A.S.S. (2010). Efficacy of bacterially expressed dsRNA specific to different structural genes of white spot syndrome virus (WSSV) in protection of shrimp from WSSV infection. Journal of Fish Diseases, 33, 603-607.

Tassanakajon, A., Somboonwiwat, K., Supungul, P., \& Tang, S. (2013). Discovery of immune molecules and their crucial functions in shrimp immunity. Fish \& Shellfish Immunology, 34, 954-967.

Tenriulo, A., Tampangallo, B.R., Parenrengi, A., \& Dewi, R.A. (2016). Isolasi dan karakterisasi gen penyandi protein VP-24 WSSV pada udang windu (Penaeus monodon) untuk pengembangan teknologi RNAi. Prosiding Forum Inovasi Teknologi Akuakultur, hlm. 593-598. 
Witteveldt, J., Cifeuntre, C.C., Vlak, J.M., \& Hulten, M.C.W. (2004). Protection of Penaeus monodon against white spot syndrome virus by oral vaccination. J. Virol., 78, 2057-2061.

Wulandari, A.S. (2010). Konstruksi dan produksi dsRNA gonad-inhibiting hormone udang windu (Penaeus monodon) secara in vitro dan in vivo pada vektor ekspresi L4440. Tesis. Program Studi Magister Bioteknologi, Institut Teknologi Bandung.

Yeh, S.P., Chen, Y.N., Hsieh, S.L., Cheng, W., \& Liu, C.H. (2009). Immune response of white shrimp, Litopenaeus vannamei, after a concurrent infection with white spot syndrome virus and infectious hypodermal and hematopoietic necrosis virus. Fish She 